\title{
Reaching for the Tree of Life: The Role of Eating, Drinking, Fasting, and Symbolic Foodstuffs in 4 Ezra
}

\author{
Peter-Ben Smit \\ vU University/Utrecht University/University of Pretoria \\ p.b.a.smit@vu.nl
}

\begin{abstract}
This paper considers the role of foodstuffs and their (non-)consumption in 4 Ezra. While foodstuffs figure prominently in this work, no systematic research has been done into it. The paper argues that both the narrative progression of the work is expressed through foodstuffs as well as significant parts of the work's content.
\end{abstract}

\section{Keywords}

food - fasting - tree of life - meals - 4 Ezra

\section{Introduction}

In $4 \mathrm{Ezra}^{1}$ foodstuffs, as well as behavior related to their (non-)consumption, play a role of considerable importance. Indeed, it is a striking feature of 4 Ezra,

* I am grateful to the comments of anonymous reviewers of the Journal for the Study of Judaism on an earlier version of this paper and to Pegram Johnson III for proofreading it.

1 I mean here chs. 3-14 of what is known as 4 Ezra in some traditions; therefore, I do not include chs. 1-2 (5 Ezra), or chs. 15-16 (6 Ezra). The text that is followed here is the one provided (in translation) by Michael E. Stone, Fourth Ezra (Hermeneia; Minneapolis: Fortress, 1990); the translations below also take into account Stone's text-critical notes. To be sure, in the chapters that were added later foodstuffs, eating, and drinking also occur, notably in: 1:19-24 (provision of food in the wilderness during the exodus; 1:31 (rejection of food/meal fellowship in the form of oblations by God; 2:12 (tree of life); 2:18-19 (abundance in a future paradise); 2:25 (a nurse is to nourish her children); 2:38 (the feast of the Lord); 15:19 (hunger); 15:53 
and yet it is equally striking that to date no such study of this topic exists. This constitutes a gap in the research on 4 Ezra that this paper seeks to fill. Research on foodstuffs and eating and drinking in 4 Ezra is of relevance for a number of reasons. First, as was already indicated, foodstuffs and their consumption are prominent in 4 Ezra; this invites their more thorough consideration from a literary point of view. Second, in combination with the first point I would add the observation that foodstuffs and their meaning were of high importance in the social world of Ezra, as they embodied, expressed, constructed, or symbolized a range of meanings. To be sure, 4 Ezra is understood here as a late Second Temple Period writing that seeks to respond to the theological crisis provoked by the destruction of Jerusalem, ${ }^{2}$ especially with regard to traditions, such as the sapiential one, ${ }^{3}$ that emphasized the sanctity and significance of Jerusalem.

The question guiding the topic addressed here is the following: what is the significance of this frequent occurrence of foodstuffs and food-related symbolism in 4 Ezra? The following steps will be taken to answer it: after introducing the topic and presenting the research question, an overview of the significant aspects of meals, foodstuffs, and food-related symbolism in the social world of 4 Ezra will be given with a particular focus on those aspects that will be of relevance for the study of foodstuffs and their use in 4 Ezra; then, the motifs of fasting and non-fasting, the association of the world to come with

(drunkenness); 15:57-58 (hunger); 15:62 (fruitful trees and their demise); 16:18-19 (famine); 16:21 (cheap provisions); 16:24 (trees bearing fruit for no one); 16:29-30 (olives and grapes); 16:33 (no wedding feasts); 16:34 (famine); 16:43, 46 (strangers gathering the fruits of those who labor for them); and 16:69 (food offered to idols).

2 The discussion about the social location of 4 Ezra is far from concluded. For example, Stone, Fourth Ezra, 9-11 and 36-43, takes a very reluctant approach (e.g., on p. 40: "[W]e do not know how the book functioned and to whom it was directed"). Jürgen Kerner, Die Ethik der Johannes-Apokalypse im Vergleich mit der des 4. Esra (BZNW 94; Berlin: De Gruyter, 1998), 17475, remains close to this view, while Philip F. Esler, "The Social Function of 4 Ezra," JSNT 53 (1994): 99-123, argues that the work was intended both to come to terms with the cognitive dissonance caused by the destruction of the Temple and to rally the people of Israel to unite once again around the Law. Bruce W. Longenecker, "Locating 4 Ezra: A Consideration of its Social Setting and Functions," JSJ 28 (1997): 271-93, is even more specific, arguing that the work needs to be located in the post-7o Yavneh community, where a scribe attempted to provide leadership by means of 4 Ezra - a work that was intended by him as an instruction manual. For a critical review of this position and an argument for 4 Ezra as an "esoteric" work, see Karina Martin Hogan, Theologies in Conflict in 4 Ezra: Wisdom Debate and Apocalyptic Solution (JSJSup 130; Leiden: Brill, 2008), 222-27.

3 See, e.g., Hogan, Theologies, 35-40; also Kerner, Ethik, 175-76, as well as Esler, "Function," 99-123. 
an abundance of foodstuffs, and the symbolic use of foodstuffs in 4 Ezra will be addressed. This will be followed by a few concluding remarks. Given this approach, more emphasis will be placed on a literary analysis of the function of foodstuffs and their (non-)consumption in 4 Ezra than on their traditionhistorical background, ${ }^{4}$ or on the role they played in the history of reception of 4 Ezra.

Research into the sociology of meals-especially in relation to early Christian and Jewish writings- has shown that, in general, foodstuffs and their use are closely related to the following topics:

- Social bonding can be expressed through meal fellowship or the rejection thereof (including fasting); thus, meals are expressive of social relationships and the fabric of a society or a group within society; ${ }^{5}$

- The (non-)consumption of particular foodstuffs, e.g., because of dietary regulations, is of high importance given their function as identity markers; ${ }^{6}$

- The use of foodstuffs and their (non-)consumption is of importance for the identification of the character of events or, for example, the mood or status of a person. ${ }^{7}$

- Particular foodstuffs are associated with particular events or places, and

- their (non-)consumption aids the identification of the (non-)belonging of persons or places to, for example, deities, holiness, profanity, etc. ${ }^{8}$

Both the actual use or non-use of foodstuffs and its social implications (bonding and separation, indication of social hierarchies) as well as their metaphorical use (e.g., wine and its association with joy, or manna and its association

4 For an overview of recent research, see Hogan, Theologies, 1-35, and Stone, Ezra, 1-47.

5 See, e.g., Peter-Ben Smit, Food and Fellowship in the Kingdom (wUNT 2.234; Tübingen: Mohr Siebeck, 2008), 14-34, 83-96; see further the following newer publications: Hal Taussig, In the Beginning was the Meal (Minneapolis: Fortress, 2009), 21-86, Hans Joachim Stein, Frühchristliche Mahlfeiern: ihre Gestalt und Bedeutung nach der neutestamentlichen Briefliteratur und der Johannesoffenbarung (WUNT 2.255; Tübingen: Mohr Siebeck, 2008), 27-95.

6 See, e.g., Smit, Food, 95-96, and further: Peter J. Tomson, "Jewish Food Laws in Early Christian Community Discourse," Semeia 86 (1999): 193-211, Albert I. Baumgarten, "Finding Oneself in a Sectarian Context: A Sectarian's Food and Its Implications," in Self, Soul, and Body in Religious Experience (ed. Albert I. Baumgarten, Jan Assmann, and Guy G. Stroumsa; Leiden: Brill, 1998), 125-47, and Veronika E. Grimm, From Feasting to Fasting. The Evolution of a Sin (New York: Routledge, 1996), 1-13.

7 See, e.g., Smit, Food, 95 .

8 See, e.g., Smit, Food, 28-30, 94-95. 
with both the past and the future eschatological Exodus) are therefore of importance for the analysis of 4 Ezra.

When focusing on 4 Ezra itself, it will become clear, as will be demonstrated more extensively below, that the foodstuffs and acts of eating and drinking as they occur in 4 Ezra may be organized into three main groups of passages. Though, a number of scattered remarks about foodstuffs remain that are neither related to one of these groups nor to the main focus of 4 Ezra. ${ }^{9}$ In this contribution, the latter will not be discussed separately. Instead, only the three main groups will be analyzed which correspond to three themes related to foodstuffs and their use: a) fasting and non-fasting; b) the association of the world to come with nutritional abundance; and c) the symbolic use of foodstuffs, especially in relation to "paradise" and "righteousness." ${ }^{10}$ In category "c," a further distinction will be made between the production and the consumption of symbolic foodstuffs, while the issue of drinking will be given separate attention as well, given that it seems to lead to questions of its own. Before turning to these passages themselves, a brief overview of the most important uses of foodstuffs in the context of early Judaism and the Hebrew Bible/ Septuagint will be given in order to provide some background for how they appear in 4 Ezra.

A) Fasting and non-fasting. As will be discussed below, fasting and non-fasting - as well as the progression from the one to the other-play a very important role in 4 Ezra. In early Judaism, obligatory fasting was prescribed only on the Day of Atonement. ${ }^{11}$ However, many kinds of voluntary (and often conventional) fasting existed as well, especially among penitential movements in early Judaism (e.g., the followers of John the Baptist), or among those

They include: 3:24 (oblations, possibly indicating meal fellowship), 4:48-50 (water and rain), 7:104 (eating and drinking as an act that cannot be substituted), 7:114 (sinful indulgence, possibly including eating and drinking), 9:22 (comparison of Israel to grape and vine), 9:47 (wedding feast), 10:14, 16 (fruit of the womb, fruit of the earth), 12:39 (a comparison involving a cluster of grapes), and 14:42 (eating bread at night).

10 It may be noted, in this context, that the topic of meal fellowship and its dynamics- to which 4 Ezra, strikingly, does not refer in any substantial way (except in a negative way, i.e., Ezra refrains from it) — will not play a significant role in this paper. The reasons for the absence of the topic of meal fellowship are unclear, though they may be related to the esotericism of the book and Uriel's emphasis on Ezra being different from all others.

11 On voluntary and obligatory fasting in the Old Testament/Hebrew Bible and early (rabbinic) Judaism, see: Grimm, Feasting, 14-33 and Peter Gerlitz, "Fasten/Fasttage: I. Religionsgeschichtlich," TRE 11:42-45. 
advocating a more intense dedication to the Law, such as the Pharisees. ${ }^{12}$ These occurrences of fasting continued conventions established in the Hebrew Bible, where fasting was appropriate in the context of repentance and confession: ${ }^{3}$ i.e., when forgiveness, atonement and healing were sought, ${ }^{14}$ or in the context of intense dedication, ${ }^{15}$ prayer, ${ }^{16}$ or mourning. Fasting identified the person, or group, engaging in it with a (temporary) rejection of life and/or, for various purposes, a rejection of (meal) fellowship with others. Joyful occasions, notably the celebration of a wedding, constituted the antithesis to fasting and provided occasions on which fasting would be highly inappropriate. ${ }^{17}$

B) The association of the world to come with nutritional abundance. The "world to come" was in early Judaism — as well as the Greco-Roman worldclosely associated with a return to the paradisiacal conditions of fertility and nutritional abundance. In the Hebrew Bible, eschatological nutritional abundance or, alternatively, the abolition of hunger and thirst occur within the context of passages dealing with the (eschatologically connoted) return

12 For the followers of John the Baptist as an exceptional penitential movement, see Q 7:33; and the disciples of the Pharisees as advocates of a stricter piety, see, e.g., Richard Thomas France, The Gospel of Mark (NIGTC; Grand Rapids: Eerdmans, 2002), 138 and Robert A. Guelich, Mark 1-8:26 (WBC 34A; Dallas: Thomas Nelson, 1989), 109; compare, e.g., Luke 18:12.

13 See, e.g., 1 Kgs 2:21, 27-29 and Neh 1:4.

14 See, e.g., Dan 9:3, Pss. Sol. 3:6-8, and also Apoc. El. 1:21; for examples of penitential fasting, see further: Lev 16, 1 Kgs 21:27, Isa 58; and for mourning see, e.g., Esth 4:3, 1 Sam 21:13, Jdt 8:6.

15 For fasting as a means of purification and dedication, see Jos. Asen. 10:17 (and further: 11:2, 6, 12, 17, 13:1, 15:3) and Pss. Sol. 3:8. On this, see, e.g., Wolfgang Schenk, "Die rhetorische Funktion der Fastenwarnung Mk 2,20," in Sayings of Jesus: Canonical and Non-Canonical (ed. William L. Petersen, Johan S. Vos, and Henk J. de Jonge; Leiden: Brill, 1997), 251-76, 273-76.

16 For supplicant fasting, see 2 Sam 12:21-23, Ezra 8:23, Jonah 3:5-9 (LXX), Pss. Sol. 3:8-9, and the rabbinic examples given by Ulrich Mell, "'Neuer Wein (gehört) in neue Schläuche' (Mk 2,22c)," ThZ 52 (1996): 1-31, here 18-19.

17 Even when, after the destruction of Jerusalem, elements of mourning were introduced into Jewish wedding ritual, see Ruben Zimmermann, Geschlechtermetaphorik und Gottesverhältnis (WUNT 2.122; Tübingen: Mohr Siebeck, 2001), 285-86. 
from the exile, ${ }^{18}$ or with blessings following Israel's repentance. ${ }^{19}$ The theme is part of the broader topic of the restoration of creation as a consequence of the returned divine favor. ${ }^{20}$ Examples include Isa 49:10, ${ }^{21}$ while the invitation in Isa 55:1-2 functions along similar lines, as does Isa 65 (esp. vv. 13-14); whereas an extensive scenario is outlined in Ezek 36:21-38 in which the restored Israel is explicitly compared with the Garden of Eden (cf. Ezek 36:35). The motif also appears in Zech 9:17. ${ }^{22}$ In the Psalms nutritional abundance is also a sign of the divine rule (see, e.g., Ps 22:27). With respect to the motif of the divine shepherd whose task includes the provision of nutrition for his flock, Ezek 34:23-31 is also of relevance, as well as Ps 23:1-3, 5. In Joel 2:18-27 and 4:18, the Day of the Lord brings about an abundance of foodstuffs. In considering the New Testament texts as a context for the interpretation of 4 Ezra as well, then attention may be drawn to texts such as Q 6:21a (Luke 6:21a/Matt 5:6), John 4:13-14, 6:35, Rev 7:16-17, and 21:6. The various references to eschatological foodstuffs (tree of life, water of life, and the hidden manna) in Revelation are probably also best interpreted in view of the book's progression to a "paradise regained" in Rev 21-22. Also, the gift miracles in Mark 6:32-44par. and 8:1-10par. (with John 6:1-15), and those in Luke 5:1-11, John 2:1-11, and 21:1-14 focus on the theme of nutritional abundance, which is, in John, the conceptual background of the water of life discourse in John 4:1-42 and the bread of life discourse in John 6:22-59. Needless to say, references to (the restoration of) nutritional abundance in the eschaton are found in a number of non-canonical texts (apart from 4 Ezra), including: 1 En. 10:18-19 and 2 Bar. 29:5-7. ${ }^{23} \mathrm{~A}$ similar notion is found

18 See Daniel S. Steffen, "The Messianic Banquet as a Paradigm for Israel-Gentile Salvation in Matthew" (Ph.D. diss., Dallas Theological Seminary, 2001), 45-113; cf. Isa 1:19, 9:3 27:2-6, 12-13, 29:17-24, 30:19-29, 32:1-8, 49:5-13, 51:3, 55:1-2; in Ezekiel the same relationship between lack of food during the exile (4:13-17, 5:10, 12, 16-17, 6:11-12, 7:15, 19, 12:16-20, 14:13, 21) and its abundance after Israel's restoration (34:13-16, 27, 29, 36:8-15, 29-30, 34-35, 37) can be observed.

19 See Steffen, "Banquet," 47-48.

20 See already in Isaiah: 1:19, 9:3, 27:2-6, 12-13, 29:17-24, 30:19-29, 32:1-8, 49:6-13, 51:3, 55:1-2; with a relationship to the coming of the Messiah: Isa 9:6-7, 24:23, 26:1-4, 15-19, 27:6, 13, 35:1-10, $43: 5-7,45: 20,49: 8-13,22-23,51: 11-14,54: 7,60: 4-14$; and with the inclusion of the nations or the dispersion: Isa 2:1-4, 9:1, 11:10-12, 18:7, 19:18-25, 42:6, 49:6-7, 22-23, 56:3, 61:7, 66:21 (cf. Steffen, "Banquet," 48).

21 See also Steffen, "Banquet," 48.

22 See for the same dynamics already noted for Isa and Ezek. in Zech: 1:17, 3:8-10, 8:11-12.19, 9:15-17, 10:1; see also: Steffen, "Banquet," 65-66.

23 See also Irenaeus' quotation of Papias in Haer. 5·33:3-4. 
in Sib. Or. 3:619-623, which describes the state of affairs after the judgment on the nations. ${ }^{24}$ Apoc. El. 1:9 (probably drawing on Rev 3:12, 7:3, 16, 14:1) stands in the same tradition. Among the Dead Sea scrolls, 4Q171 2:10-11, ${ }_{11} Q_{13}$, and $4 Q_{521} 5$ ii 5-13 should be mentioned.

C) The symbolic use of foodstuffs, especially in relation to "paradise" and "righteousness." As was already indicated, a number of foodstuffs fulfill roles that go beyond nutritional or social functions; their significance is primarily to be found in their symbolic nature. Among these foodstuffs, the tree of life and its fruit are of primary importance for the interpretation of 4 Ezra. The tree of life as a component of the paradisiac garden (in addition to Gen 2-3, see Ezek 31:2-9) is part of a wide range of tree-symbolism in the ancient Near East, which cannot be discussed here separately. ${ }^{25}$ The expression "tree of life" as such occurs in the Hebrew Bible/Old Testament in Gen 2:9, 3:22, 24 and Prov 3:18, 11:30, 13:12, 15:4, though only in Genesis is eating from (the fruits of) this tree in view. Moreover, none of these instances is clearly eschatological, although Gen 2-3 certainly reflects protological utopian thought. In the New Testament, there are four references to this motif. They are all found in Revelation $(2: 7,22: 2,14,19),{ }^{26}$ where they function as an eschatological reward for the faithful, envisaged as a partaking of the blessings of the eschatological paradisiac garden, i.e., the heavenly Jerusalem. In the non-canonical literature (excluding 4 Ezra), a number of references to the tree of life can be found in the context of eschatological expectations. Within the Enochic corpus, both 1 En. 25:4-5 and 3 En. $23: 18$ refer to eating from the tree of life as part of the eschatological reward for the righteous. T. Levi 18:11, ${ }^{27}$ T. Jac. 7:23-24, Apoc. Mos. 28:4, and Apoc. El. 5:6 all refer to enjoying the (fruit of) the tree of life in the world to come along similar lines. Of significance for the interpretation of 4 Ezra is the equation of the tree of life and the Torah, both of which could be considered as eschatological entities or as part of the contents of "paradise." ${ }^{28}$ As will become clear in the course of this study, 4 Ezra offers an interesting combination of the

\footnotetext{
24 See Steffen, "Banquet," 68-70.

25 See, in general, Silvia Schroer, "Lebensbaum," Neues Bibel-Lexicon 2:602-3.

26 See David E. Aune, Revelation 1-5 (WBC 52A; Nashville: Thomas Nelson, 1997), 151-54, for a brief tradition history.

27 Possibly a Christian interpolation. So, e.g., Aune, Revelation $1,15^{2}$.

28 See, e.g., Aune, Revelation 1-5, 153-54. See also 4 Macc. 18:16, quoting Prov 3:18, where the one who does God's will is compared to a tree of life.
} 
notions of the tree of life (i.e., Torah) in the world to come and the bringing forth of the fruits of the law (i.e., as the tree of life) in Ezra's day and age. ${ }^{29}$

With this broad background of foodstuffs, their use, and their symbolic significance in mind, this paper will now explore how the use of foodstuffs and (non-)eating and drinking are expressive of the issues addressed by 4 Ezra, both with regard to the role of Ezra himself, and also with regard to the teaching that the work seeks to communicate. ${ }^{30}$

First, the topic of fasting in 4 Ezra will be discussed. This issue is the one most closely related to the literary progression of 4 Ezra and is evident by the fact that the beginnings of most visions and dreams are related to fasting or other food-related behavior on the part of Ezra. Likewise, the fourth vision-consisting of Ezra's encounter with a (mourning and fasting) woman-represents a turning point in the whole of the work by means of an account that uses the motif of fasting. Furthermore, as will be shown, the progression in divine-human communication - from dreams, to visions, to speaking wisdom in the final episode of the work-is closely matched by shifts in food-related behavior: namely, the development from fasting, to the eating of flowers, to the drinking of a fiery liquid.

\section{1 $\quad$ Fasting and Non-Fasting}

When considering the topic of fasting and non-fasting in 4 Ezra, one observes first that fasting and the abridgement of fasting by Ezra is closely related to the structure of the work, which is dominated by a sequence of seven visions: (1) 3:1-5:20a; (2) 5:20b-6:34; (3) 6:35-9:25; (4) 9:26-10:59; (5) 11:1-12:51; (6) 13:1-58; and (7) 14:1-49. ${ }^{31}$

29 See, e.g., 3:20, 8:41, 9:30-37; in New Testament texts, bringing forth fruit is associated with repentance and doing righteousness; see, e.g., Matt 7:15-20, 21:43, John 15:1-16, Rom 6:22, 7:4-5, and Gal 5:22-23; for the sowing of the Word, see, e.g., 1 Cor 3:5-9 and Mark 4:1-9par.; and for some of the conceptual background, see Isa 55:10-11, Hos 10:12, Prov 11:18, 30-31, Job 22:21 (LXX), Sir 1:16-18, 6:18-19, 37:22-23, and further Job 4:8. See, e.g., John R. Donahue and Daniel J. Harrington, The Gospel of Mark (SP; Collegeville: Liturgical Press, 2002), 142.

$30 \quad$ For an overview, see, e.g., Stone, Ezra, 35-36, Josef Schreiner, Das 4. Buch Esra (JSHRZ 5.5; Gütersloh: Gütersloher Verlagsbuchhaus, 1981), 291-309, Hogan, Theologies, 1-40 (esp. 35-40), and Kerner, Ethik, 6-32.

31 See, e.g., Stone, Ezra, 50-51. 
Although the first vision, which is concerned with the topic of God's justice, ${ }^{32}$ is not explicitly introduced with a reference to fasting on Ezra's part - the topic is only mentioned explicitly for the first time in 5:20-a remark in 6:35 about Ezra's fasting for three weeks strongly suggests that Ezra had been fasting for the duration of the first vision and possibly some time before it as well. Should this indeed be the case, then Ezra's mood during the vision, which described as "troubled" in 3:1, would be very fitting.

The second vision, as such, is less concerned with the question of God's (ultimate) justice, than with God's handling of it (i.e., how God treats Israel in this world). ${ }^{33}$ Yet, significantly, it is introduced by means of a section on fasting. In 5:20, Ezra fasts in order to prepare for his second vision ${ }^{34}$ or, rather, for his second time of addressing God. ${ }^{35}$ Ezra's fasting here may well have multiple (complementary) functions and meanings. To begin with, the angel Uriel commands Ezra to fast in 5:13, and Ezra does so, sending away the "chief of the people" Paltiel, who wanted him to eat after the ordeal of the first vision (5:14-15; for Paltiel, 5:16-20a). In 5:20b, Ezra complements his seven days of fasting with mourning and weeping. Both of these developments give indications as to the direction in which this fasting goes and to its meaning. First, fasting functions as a means of dedicating oneself to God, probably specifically in effort to communicate with God (in separation from the rest of the people). Second, fasting is also an expression of mourning, likely because of the destruction of Zion/Jerusalem (see 5:23-30). Finally, fasting can be an expression of penitence, which would suit Ezra's mood here as well. Given the context provided by Ezra's visionary experiences, his fasting may also be associated with ascetic techniques for inducing visions or an altered state of consciousness (even if

32 As Stone, Ezra, 63 puts it: "Human free will, Ezra claims, is meaningless, if the ultimate result of human action is, in any case, inevitable punishment because of the very way the world is constituted by its divine creator." See also Stone's further considerations in "The Way of the Most High and the Injustice of God in 4 Ezra," in Selected Studies in Pseudepigrapha and Apocrypha: With Special Reference to the Armenian Tradition (ed. Michael E. Stone; Leiden: Brill, 1991), 348-58.

33 E.g., by letting them be punished by the Romans (5:29-30). As Stone, Ezra, 127, puts it: "Ezra seems to have moved from his doubt about God's justice to bewilderment at his actions."

34 This reading is generally accepted; see Schreiner, Esra, 326, and cf. 2 Bar. 9:2, 12:5, and 21:1. See also Matthias Henze, Jewish Apocalypticism in Late First Century Israel: Reading Second Baruch in Context (TSAJ 142; Tübingen: Mohr Siebeck, 2011), 133.

35 See the discussion by Stone, Ezra, 118-19. 
this is not addressed explicitly in 4 Ezra, it may be implied). ${ }^{36}$ The result of this period of fasting is that Ezra receives the spirit of understanding and begins to speak to God again $(5: 22)$.

Turning to the beginning of the third (and longest) vision, it is striking that again it is preceded by intense fasting on the part of Ezra. Indeed, the introduction is very similar to that of the second vision, and the distress of his soul prompts him to speak in the presence of the "Most High" (6:35-36). ${ }^{37}$ In the same verse (v. 36), the reference to three weeks of fasting that had been prescribed to Ezra (even if it is unclear by whom and when) ties together the first three visions with fasting, given that Ezra will change his behavior from now on.

The transition from the third to the fourth vision is again prompted by particular food-related behavior on the part of Ezra. Unlike in the previous two transitions, this time Ezra is specifically instructed not to fast, but to go out into a field and to subsist on a diet of only flowers for a week (this corresponds with the remark in 6:35 that Ezra's period of fasting is now completed). It is not stated explicitly what sort of flowers these are, nor what their intended effect is. The broader context of 4 Ezra does provide some clues, though. To begin with, it is probably relevant that in 6:44 flowers are mentioned as part of the contents of the primordial garden. Furthermore, as Moo has argued, Ezra can also be seen as participating in the paradise to come (or to be revealed), since the future Zion is revealed to be precisely in the same field where Ezra is eating his flowers in 10:53-54. ${ }^{38}$

In light of this background, it should also be noted that, from the point of view of the contrast between Ezra's minimal diet in 9:23-25 with the fasting of the two earlier transitions, the apocalypse continues in a lighter tone. Mourning, fasting, and penitence have disappeared; only abstinence from rich food (meat and wine, 9:24) remains. Ezra does as instructed in 9:26, "I

36 See, e.g., Henze, Apocalypticism, 133, and compare: Exod 34:28, Deut 9:9, Dan 9:3, 10:2-3, Ascen. Isa. 2:10-11, Apoc. Ab. 9:7, 12:2, 3 Bar. 3:14. See further, e.g., Christopher Rowland, The Open Heaven: A Study of Apocalyptic in Judaism and Early Christianity (New York: Crossroad, 1982), 228-229 and Eliezer Diamond, Holy Men and Hunger Artists: Fasting and Asceticism in Rabbinic Culture (Oxford: Oxford University, 2004), 97.

37 On a side note, one may remark here that the obvious decrease in Ezra's distress and mourning while the visions keep coming renders unlikely the psychoanalytical analyses that suggest the visions originated in mourning. See, however, Daniel Merku, "The Visionary Practices of Jewish Apocalypticists," in The Psychoanalytic Study of Society: Essays in Honor of Paul Parin (ed. L. Bryce Boyer and Simon A. Grolnick; vol. 14 of The Psychoanalytic Study of Society; ed. L. Bryce Boyer et al.; Hillsdale, N.J.: Analytic, 1989), 119-48.

38 See Jonathan A. Moo, Creation, Nature and Hope in 4 Ezra (FRLANT 237; Vandenhoeck \& Ruprecht, 2011), 146-48. 
sat among the flowers and ate of the plants of the field, and the nourishment they afforded satisfied me." The flowers here are, as in 6:44, reminiscent of the flowers of "paradise."39 Having eaten these flowers and without any suggestion of distress prompting or accompanying their consumption, Ezra's mouth is opened and he again addresses God.

As part of the fourth vision, Ezra encounters a woman who mourns because she has lost her only son. He had been given to her in old age and now he has been taken from her on what should have been the most joyful day of his life, namely that of his wedding feast (9:47; this is an instance of the use of imagery related to meal fellowship and feasting). The woman is fasting because of her grief and intends to do so until she dies (10:4). ${ }^{40}$ Ezra chastises her, telling her that her own loss (of the "fruit of her womb") is nothing compared to that of Jerusalem, and that what has happened is according to the way of the earth-i.e., the earth has always given its fruit (i.e., human beings) to God (10:14). Ezra reassures the woman that her son will be returned to her in due time (10:16). This conversation with the woman, however, receives a rather unexpected twist towards the end of the vision. All of a sudden, the woman is transformed into (a vision of) the heavenly Jerusalem and, because of his sincere concern for Jerusalem, Ezra is told that the fate of the woman was in fact the personified fate of Jerusalem (see also the eschatological city mentioned in 8:52). In many ways, this encounter constitutes a major, if not the major, turning point of 4 Ezra, for Ezra himself now begins to be consoled and to understand God's view of things. ${ }^{41}$

The shift from the fourth to the fifth vision happens without explicit reference to food or fasting. However, there is no indication that Ezra changes his diet. In other words, he receives his fifth vision while sleeping after his first week of his flowers-only diet (11:1; note that the field of flowers is mentioned just before in 10:53). The sixth vision (or, rather, dream) is similarly introduced by a reference to Ezra's flowers-only diet (12:51). This changes, however, in the

39 This intra-textual connection makes it slightly more plausible that Ezra subsists on a "paradisiacal" diet here, rather than on some hallucinogenic herbs which induce dreams or visions. See Schreiner, Esra, 373, for notes on this diet in the various textual traditions; there is a tendency to align it with Gen 1:29.

40 Although her behavior is doubtless extreme, fasting as such is a way of refusing life because of excessive sorrow and pain and a common part of mourning rituals in antiquity. See Kerner, Ethik, 188.

41 See, e.g., the extensive argument of Hogan, Theologies, 162-73. What the content of these views is in terms of soteriology remains much discussed; consider the questions raised by Bruce W. Longenecker, Eschatology and the Covenant: A Comparison of 4 Ezra and Romans 1-11 (JSNTSup 57; Sheffield: Sheffield University, 1991), 149-57. 
seventh and last vision. Here, near the end of this larger section of 4 Ezra, the seer, who from the start of this section of the work had been addressed by the Lord directly, is commanded to go out into the field again, but this time he is to take with him scribes and supplies for the writing of books in order to dictate public and secret books. So that Ezra might be able to dictate these books, the following procedure takes place:

And it came to pass, on the next day, behold, a voice called me, saying "Ezra, open your mouth and drink what I give you to drink." Then I opened my mouth, and behold, a full cup was offered to me; it was full of something like water, but its color was like fire. And I took it and drank; and when I had drunk it, my heart poured forth understanding, and wisdom increased in my breast, and my spirit retained its memory; and my mouth was opened and no longer closed. (14:37-41 $)^{42}$

Having surveyed the various occurrences of (not) eating and drinking in relation to Ezra's visionary experiences, dreams, and speaking of wisdom, the following may be concluded with regard to this aspect of the role of foodstuffs and their consumption in 4 Ezra.

First, in terms of literary structure, it may be concluded that Ezra's fasting, eating, and eventual drinking (to be discussed below) is closely related to the structure of 4 Ezra. Fasting belongs to the first three visions, eating flowers belongs to the second three visions, and drinking a fiery liquid belongs to his eventual speaking in the seventh vision.

Second, if one disregards the terminology of "visions" as it is often used to subdivide 4 Ezra and instead concentrates more on what actually happens to Ezra, it becomes clear that as long as Ezra fasts, he receives visions, as soon as he eats flowers, he receives dreams, and as soon he drinks a fiery liquid, he speaks wisdom. In other words: the kind of experience Ezra has is directly related to what he does or does not consume.

Third, the progression - from fasting to eating flowers then to drinking a fiery liquid along with its parallel in the shift from visions to dreams then to speaking - agrees with and is expressive of Ezra's development from nonunderstanding and rebellion to his being initiated into God's view of things and thereby becoming an active proponent of these views (see also his encounter with the woman/Jerusalem in chs. 9-10). From disagreement, mourning,

42 Stone, Ezra, 437. For tradition- and motif-historical considerations, see p. 440; cf. also Hogan, Theologies, 214-17. 
and fasting, Ezra moves to agreement, eating, and drinking. ${ }^{43}$ To begin with, Ezra's distress decreases during the first three visions the more he learns about God's ways. The fourth vision, i.e., the first dream introduced by Ezra's more life-affirming eating of plants, provides a turning point through Ezra's encounter with the mourning and fasting woman that is transformed into a new Jerusalem. This encounter as well as Ezra's teaching (and subsequent learning) role in it are expressive of Ezra's continually growing insight. They also match his own shift from fasting to eating and set the tone for the remaining two dreams. Having gone through all of this, Ezra's speech in the final section of the work is introduced by drinking a special liquid (14:37-41). This leads to his overflowing with words of wisdom as someone who has been fully initiated into the ways of God and can now communicate them to others. Although all of these ways of preparing oneself for visionary experiences have analogies in other prophetic and apocalyptic texts from an early Jewish or broader GrecoRoman context, ${ }^{44}$ for the understanding of 4 Ezra in particular the narrative progression with regard to foodstuffs and visionary experiences is of importance as they match the development in the character of Ezra.

Fourth, given the social and symbolic significance of fasting and eating and drinking, the aforementioned literary development also signifies a movement from death to life. Quite in line with this is the encounter between Ezra and the woman/Jerusalem in chs. 9-10. There, Ezra's active exposition of what he has learned so far also produces a change in the woman-she transforms from being someone intent on fasting till death into a heavenly city. The author of 4 Ezra thus shows himself to be very familiar with the social significance of fasting (and the practice thereof) as it relates to communication with the divine, penance, and mourning. Moreover, he probably assumes that his audience is equally familiar with this practice, which, in turn, sheds light on the profile of the community for which the work was authored.

\subsection{The Association of the World to Come with Nutritional Abundance}

There are a number of instances in 4 Ezra where "paradise" or the world to come is described in relation to foodstuffs and/or abundance. The following examples are particularly noticeable.

43 This is in line with other behavior on the part of Ezra, such as praising God (13:57), coming from earlier mourning, and in contrast with the mourning of others; Ezra's behavior is, just like his change of mind, paradigmatic. See, e.g., Kerner, Ethik, 185.

44 See, e.g., Adela Yarbro Collins, Cosmology and Eschatology in Jewish and Christian Apocalypticism (JSJSup 5o; Leiden: Brill, 2000), 8, 17-18. 
First, in 6:44 the amount of fruit of the primordial garden is emphasized as an abundance, which is also said to be a characteristic of the world to come in general in 7:123. The context of the reference to the abundance of fruits in 6:44 is a description of the creation of the world, where on the third day "immediately fruit came forth in endless abundance and of varied appeal to the taste, and flowers of inimitable color, and odors of inexpressible fragrance" (cf. Gen 1:11-12). ${ }^{45}$ All but the Latin textual traditions add a reference to trees here; it seems to be consistent with the general imagery of 4 Ezra to indeed expect these here as well. ${ }^{46}$ For the present discussion, the appearance of the fruit is of particular importance here, given that it recalls the other fruits that were already mentioned in 4 Ezra. Apart from the fruit of the seed of evil (4:30-31), these were eschatological fruits of righteousness that were associated with the redeemed and renewed world to come (3:20, 6:28). From 6:44 onwards, the image of the fruit is enriched with a further dimension-its close (and now explicitly stated) relationship with "paradise."

In 7:123 paradise, the age to come, and fruits are brought together, where the world to come is described in a consideration of its accessibility for those struggling on earth. Here, Ezra describes the following place: "a paradise ... whose fruit does not spoil and in which are abundance and healing." ${ }^{37}$ The three associations that were already attached to the notion fruit - namely, its relation to paradise, its abundance, and its connection with the world to come-are now summed up in one comprehensive image which, incidentally, also conceptualizes the world to come as a "return to paradise."

In many ways, though without an explicit reference to fruits, this construction returns in 8:52. Here, paradise is presented as being opened for the humbled and righteous, while the tree of life is planted there for the same and "plenty is provided." 48 Also, a "city" is referred to in this context, which probably refers to the heavenly (or eschatological) Jerusalem.

Thus, in 4 Ezra, the conditions of "paradise" in the Urzeit and in the Endzeit are both conceptualized in terms of an abundance of foodstuffs, or more precisely, in terms of an overabundant fertility of creation.

45 Stone, Ezra, 178; for a comparison with the Genesis account see K. William Whitney, Two Strange Beasts: Leviathan and Behemoth in Second Temple and Early Rabbinic Judaism (HSM 63; Winona Lake: Eisenbrauns, 2006), 35-38.

46 See Schreiner, Esra, 339 .

47 See Stone, Ezra, ad loc. and Schreiner, Esra, 359, who notes the other versions (except the Latin) refer to "Wonne" rather than "Sättigung."

48 Following Stone, Ezra; Schreiner, Esra, 369, notes that the other versions (except the Latin) follow a similar pattern of differences as in 7:123. 


\section{$2.3 \quad$ The Symbolic Use of Foodstuffs}

When considering the category of symbolic foodstuffs as it was identified above, a distinction should be made between the production and the consumption of symbolic foodstuff. The issue of drinking is given separate attention, as well, given its tendency to provoke questions and literary connections of its own.

\subsubsection{The Production of Symbolic Foodstuffs}

When considering the production of foodstuffs in 4 Ezra, the following may be observed. The first foodstuff, a fruit, is mentioned in the context of the first vision in 3:20. This verse accuses God of not removing the evil heart from the people of Israel so that the law would be able to bring forth fruit in them (cf. 3:33, 4:30, 6:28, and 8:6).49 A remark that occurs in 4 Ezra 9:31 may provide a broader and soteriological line of thought to which 3:20 is also related: "I will sow my law in you, and it shall bring forth fruit in you, and you shall be glorified through it forever." 50 This expression is likely connected to further imagery of foodstuffs and eating and may also be connected with the reference to a "garden" in $3: 6 .{ }^{51}$ Thus, the metaphor used here may well be related to the notion of the tree of life (see also 4 Ezra 7:13, 7:123, and 8:52) which is planted in paradise and provides life eternal for those who have access to it. At the same time, in early Judaism references to wisdom being compared to a tree of life were interpreted in terms of the Torah (e.g., Prov 3:18, see also 11:30). Moreover, in Sir 24:12-17, paradise imagery occurs in relation to wisdom, which is then related to eating the fruits of wisdom in Sir. 24:19. These connections also form the background to 4 Ezra 3:20.52 Thus, 3:20 seems to relate the keeping of the Torah to having the seed of the law, a metaphor made possible by the equation of the tree of life and Torah, which is sown into someone (or into the people of Israel) and will result in bringing forth the fruit of the law. ${ }^{53}$

49 On this issue, and the following discussion, see: Stone, Ezra, 73, as well as Shannon Burkes, God, Self, and Death. The Shape of Religious Transformation in the Second Temple Period (JSJSup 79; Leiden: Brill, 2003), 194-96.

5o Stone, Ezra, 73. Schreiner, Esra, 374, notes the reference to fruits of the Law in 2 Bar. 32:1

$5^{1}$ Or, following, Schreiner, Esra, 312, related to "Paradies." On this motif, see, e.g., Eibert J. C. Tigchelaar, "Eden and Paradise: The Garden Motif in Some Early Jewish Texts (1 Enoch and Other Texts Found at Qumran)," in Paradise Interpreted: Representations of Biblical Paradise in Judaism and Christianity (ed. Gerard P. Luttikhuizen; Leiden: Brill, 1999), 37-62; see also Smit, Food, 15-19.

$5^{2}$ See Stone, Ezra, 73 .

53 See the discussion by Stone, Ezra, 73, 123, 198-99, 259, 266, 286. This connection seems to be primary for 4 Ezra, but see also the broader overview provided by Veronika Bachmann, 
The bringing forth of fruit occurs once more in 3:33, where Ezra states that there has been no reward for the faithfulness and labors of Israel for its deity. ${ }^{54}$ In other words, Ezra's question is: what good does obeying the Law do with regard to the well-being of the nation that keeps it, specifically in this world? ${ }^{55}$ In 3:56 Ezra reiterates this question, noting that the nations have abundance - possibly also including an abundance of food - while Israel goes empty-handed.

How this world and the world to come relate to each other is again expressed in terms of fruits in 4:31, where Uriel, Ezra's angelic interlocutor, dwells at length on the seeds of evil that produce equally evil fruits (in human beings). This kind of fruit will be "harvested" in the eschaton, as Uriel points out, using a familiar image for the eschatological judgment. Even if Uriel does not spell it out explicitly, the implication is that bringing forth fruit of evil on earth is fruitless in the world to come. At the same time, it is indicated that the clearing away of the evil growths will make space for the good ones to grow (see 3:28-29). This is the case both in the world itself as well as in the hearts of the human beings involved, thus allowing whatever good seed was already beginning to grow to finally bring forth fruit. ${ }^{56}$ This also amounts to the clearing away of the evil from the hearts and minds of those in whom the good seed had already taken root. ${ }^{57}$

Furthermore, the imagery of seeds and the fruit that they (eventually) bring, as they appeared in the first vision, returns in the second vision. This occurs specifically in a section that treats the eschatological judgment in somewhat more detail, stating that

[I]t shall come to pass that whoever remains after all that I have foretold to you shall himself be saved and shall see my salvation and the end of my world. And they shall see the men who were taken up, who from their birth have not tasted death; and the hearts of the earth's inhabitants shall

"Rooted in Paradise? The Meaning of the 'Tree of Life' in 1 Enoch 24-25 Reconsidered," JSP 19 (2009): 83-107, which may be applicable to 4 Ezra as well.

54 The efforts or labors of Israel are, according to Schreiner, Esra, 316, a reference to the efforts required to keep the Law.

55 See Burkes, God, 194-96.

56 One of the things that Ezra learns during his seven visions is that the situation is not as bleak as he indicates at the beginning, i.e., the Law is more efficacious than he thinks, and evil is not as strong as it seems. See, e.g., Burkes, God, 215-17, and Michael P. Knowles, "Moses, the Law, and the Unity of 4 Ezra," NovT 31 (1989): 257-74; the renewal of the Law in the final chapters of 4 Ezra also points in this direction.

57 See Stone, Ezra, 94-95. 
be changed and converted to a different spirit. For evil shall be blotted out and deceit shall be quenched; faithfulness shall flourish, and corruption shall be overcome, and the truth shall be revealed, which has been so long without fruit. $(6: 25-28)^{58}$

This text further develops what was already indicated in the first vision: even if the truth, or the law (and adhering to it), seems to be fruitless in the present age, in the end it will be vindicated and bring forth fruit. Divine intervention, however, is a prerequisite for this.

The image of the fruit and its production is taken up next in 8:6, this time in a prayerful request on the part of Ezra, who asks God for such a seed in his heart that it may produce fruit "by which every mortal who bears the likeness of a human being may be able to live." Following Stone, this image may be understood as a request for the seed of the law/Torah in the heart of Ezra, leading to his bringing forth of the fruit of the tree of life. ${ }^{59}$ This same theme occurs in 8:41 with reference to sowing, growing, and harvesting — a motif that is taken up once again in 9:17-21. As already noted, paradise and the tree of life occur in 8:52, as well as a reference to "plenty" for the righteous in the age to come.

Subsequently, in his address to God from 9:29 onwards, one of the first things that Ezra says is that God indeed has sown the Law in Israel and that it will bring fruit in them, even if "our fathers" did not keep the Law. The reason for Ezra's (new) confidence is that the Law and its fruit are, in fact, God's; therefore, they are indestructible (9:31). Ezra follows this with a triple inverted analogy, involving a reference to food and drink being put into a dish (9:34). He states that usually when you put one thing into the other, the thing that is inserted into the other is destroyed (or digested), but not so with the Law, given that it remains, even when its receptacle(s) perish(es) (9:37).

Then, in the fifth vision — or rather the second dream — of Ezra, a reference to the production of a foodstuff appears in 11:42, where the (righteous) inhabitants of Jerusalem are described as "those who brought forth fruit." 60

$5^{8}$ Stone, Ezra, 163. Schreiner, Esra, 337, notes that the "truth" that is referred to here is probably synonymous with the Law.

59 See Stone, Ezra, 266. See also Shannon Burkes, “'Life' Redefined: Wisdom and Law in Fourth Ezra and Second Baruch," свQ 63 (2001): 55-71 (esp. 59-61), who argues that the new understanding that Ezra receives is an indication for a renewed giving of the Law, so that Israel may keep it and live.

6o Following the Latin text here; for alternative formulations, see Schreiner, Esra, 387 . The reference here to "qui fructificabant" suits the general use of the image of bringing forth fruit in 4 Ezra. 


\subsubsection{The Consumption of Symbolic Foodstuffs}

Having considered the production of symbolic foodstuffs, their consumption may now be addressed. Aside from Ezra's flowers-only diet and the fiery liquid, both of which have already been addressed in the context of the discussion of Ezra's developing diet above, the consumption of symbolic foodstuffs occurs in two instances in particular.

First, a number of texts may be mentioned here that were already addressed in earlier sections of this paper. They concern the consumption of foodstuffs associated with paradise. These include the following: 6:44, an abundance of fruit, which is said to be appealing to the taste, in the original creation is mentioned; 7:123, non-spoiling fruits in a paradise that is to be revealed are mentioned, but not their consumption; and 8:52, the tree of life and the provision of plenty are mentioned in one verse. Furthermore, a fruit appears again in $7: 13$. Here, the fruit of immortality ${ }^{61}$ is mentioned as being provided by the entrances of the world to come. Although the world to come is not directly described as a new paradise, the reference to this fruit may resonate with earlier references to the fruit in association both with the world to come and with the primordial garden-especially in the relatively recent reference in the apocalyptic geography of $7: 36.38$ to an eschatological paradise characterized by delight.

Second, the section on the creation of the world in 6:38-55 includes a note on the Leviathan and the Behemoth $\left(6: 49-5^{2}\right)$. Both are described as creatures having been preserved "to be eaten by whom thou wilt, and when thou wilt." $(6: 52)$ This statement underlines the general drift of the "hexameron" indicating that "the world is created by God for the good of humanity." ${ }^{2}$ It certainly suits the reference to abundance in 6:44. Presumably, those who will consume these monsters (and thus ensure their destruction) are the righteous in the eschaton. ${ }^{63}$ There is more to the motif of these creatures, however. Not only does it connect the notion of the renewal of creation to creation as such, it also does the following:

61 Or "of life," according to the Ethiopic version, which would thus be related to the tree of life. See Schreiner, Esra, 343 .

62 Whitney, Beasts, 33. In fact, the remark about Leviathan and Behemoth is, as Whitney rightly notes, an expansion of the note in Gen 1:21 about the creation of the "sea monsters." See ibid., 34 .

63 See Stone, Ezra, 188 and Whitney, Beasts, 38; on the role of these beasts in Second Temple Judaism and later traditions, see Whitney, Beasts, 31-153. 
It hints at the promise of eschatological blessings for the faithful remnant of Israel and offers the assurance that those blessing are part of the divine plan written in creation. For this reason 6:49-52 serves the author of quite well. It functions as a microcosm of the second vision. On the one hand, the power of God over the monsters stands in contrast to his present inaction against Israel's oppressors. On the other, the preservation of the two beasts for the righteous heightens the tension of the moment by offering a cryptic hint of that tension's eventual solution. It suggests the impatience and frustration of the seer's community in the face of what it perceives to be God's inactivity in its present moment of crisis. It also points to the seer's answer to that impatience and frustration, his reassertion of God's eventual resolution of the crisis, through the defeat of Leviathan and Behemoth, a defeat which will actually lead to the very nourishment of God's people. ${ }^{64}$

Having thus discussed the consumption of notable symbolic foodstuffs, a brief consideration of the coherence of the "fruit" imagery will be made before turning to symbolic drinks and drinking.

\subsubsection{The Coherence of the Production of Fruits in 4 Ezra}

In 4 Ezra, the image of the "fruit" is used in a number of partially overlapping images and metaphors. These will be reflected upon systematically now.

First, there is the fruit that is brought forth by those that keep the Law (3:20; 8:6, see also 8:10, 41; 9:31-32; 11:42) and, conversely, the fruits brought forth by those who do evil (4:31). In both cases, fruit is brought forth based on something that has been sown into the heart of human beings, such as the Law or an evil inclination. A related image is that of the benefit for Israel of the keeping of the Law (3:33, referring to the lack of fruits for Israel); a benefit that, as Ezra's interlocutor indicates, will be eschatological (6:28). These fruits are related to other fruits, specifically to those that grow in the garden, i.e., paradise. Both the primordial garden $(6: 44$, see also $3: 6)$ and the eschatological paradise are characterized by fruitful trees - the latter specifically by the tree of life $(7: 123,8: 52)$ or the fruit of immortality (7:13) ${ }^{65}$ The tree of life can also be an image for the Law as such. While it would go too far to press all these images into one coherent metaphor, ${ }^{66}$ the conceptual background of all of this is the comparison of the

\footnotetext{
64 Whitney, Beasts, 38.

65 The references to the fruit of the womb or of the earth in 10:12, 14 are not related to this.

66 For cautious remarks regarding the harmonization of the eschatology/-ies of 4 Ezra, see, e.g., Hogan, Theologies, 199-204. For a consideration of the relationship between realized
} 
Torah to a tree of life, which was not uncommon in early Judaism generally ${ }^{67}$ Apparently, having sown the good seed of the law (deriving from the tree of life?) into one's heart (see 8:6, cf. 4:30-31) leads to bringing forth the fruit of the law (i.e., of the tree of life) which also means gaining access to that place where the real tree of life grows, namely the redeemed world or paradise. Ezra's view of the possibility of this happening changes throughout the apocalypse from a rather gloomy one to a more confident one. With regard to all of this, it should be noted that the imagery that uses the notion of the "fruit of the law" or the "fruit of the tree of life" is not primarily related to the consumption of this foodstuff. Rather, this particular fruit is, on the one hand, related to a particular kind of "fertility" on the part of those bringing it forth, and, on the other hand, it functions as a way of identifying the primordial garden and relating it to the "fertility" (i.e., righteousness) of the people of Israel. 4 Ezra combines the notion of the tree of life and its (assumed) equation with the Torah in an elegant way with the notion of the law (or the word of God) being sown into people and bringing forth fruit. Even though this does not lead to a completely coherent metaphor, the combination of these two notions in this way-i.e., the sowing of the word of God and the fruit of the tree of life (i.e., the Torah) still seems to be a compelling literary feat on the part of the author of 4 Ezra. ${ }^{68}$

\subsubsection{Symbolic Drinks and Drinking}

Having considered the production and consumption of foodstuffs, the focus will now turn to symbolic drinks and their use.

First, in 8:4, Ezra calls upon himself (i.e., on his soul and heart) to "drink wisdom." This, in all likelihood, is a metaphor for listening, especially in light of the rather similar — and quite literal—image for the reception of wisdom that is used later on in the work. It appear, then, that drinking and the reception of wisdom are related to one another in 4 Ezra.

and futuristic eschatology in 4 Ezra, see, e.g., Kerner, Ethik, 252-60. On the question of coherence, see also Michael E. Stone, "Coherence and Inconsistency in the Apocalypses: The Case of 'The End' in 4 Ezra," in Selected Studies in Pseudepigrapha and Apocrypha: With Special Reference to the Armenian Tradition (ed. Michael E. Stone; Leiden: Brill, 1991), 333-45, see esp. on p. 345 his notion of "associational complexes"; cf. Stone, Ezra, 204-6.

67 See the discussion by Stone, Ezra, 73, 123, 198-99, 259, 266, and 286.

68 For another view of the metaphorical coherence of the harvesting/bearing fruit imagery and analogies, see Karina Martin Hogan, "Mother Earth as a Conceptual Metaphor in 4 Ezra," свQ 73 (2011): 72-91. Hogan does not relate those "fertility" metaphors to the Paradise/Tree of Life motif, however. Still, the "mother earth" background does provide further coherence to 4 Ezra's use of images of growth and fertility. 
Second, a text that was already mentioned in the context of the relationship between fasting and non-fasting in 4 Ezra should be mentioned here again as well: Ezra's drinking of a fiery liquid in 14:37-41. The effect of this drink is, in Ezra's own words: "my heart poured forth understanding, and wisdom increased in my breast, and my spirit retained its memory; and my mouth was opened and no longer closed." This drink, it seems, has an effect on Ezra analogous to that referred to in 8:4, where the reception of wisdom in also described in terms of drinking. ${ }^{69}$ The outcome of the resulting sapiential outpouring of Ezra is described in terms that again remind one of drinks and drinking in 14:47. There, the quality of the contents of the books that were written under Ezra's guidance is described by stating that they contain "the spring of understanding, the fountain of wisdom, and the river of knowledge."

\section{$3 \quad$ Foodstuffs, Eating, and Drinking in 4 Ezra: Synthesis and Conclusions}

One may conclude, therefore, that the development of Ezra in relation to God is reflected in the descriptions of Ezra's (non-)consumption of food and drink that appear throughout 4 Ezra. Likewise, the development of the righteous is outlined in terms of foodstuffs-i.e., in terms of the fruit they produce and which is closely related to the fruit of the tree of life in paradise that they (the righteous) will attain and enjoy in the world to come (even if the emphasis is on fertility in this context, rather than consumption). This world to come is simultaneously conceptualized as a land of plenty. In other words, both the instruction that Ezra receives (which leads to an increase in understanding that the reader of his work may also receive) and the content and goal of this instruction are outlined by means of the same literary motif, namely through the help of foodstuffs.

Indeed, it could be argued that the progress of Ezra's diet from fasting, to the eating of flowers, and finally to drinking a fiery liquid is related to: (1) his increasing insight in God's wisdom, (2) the movement from death (fasting) to life (food, wisdom), and (3) Ezra's proleptic participation in paradise (flowers) and God's law or wisdom (fiery liquid, Ezra's speaking of wisdom). While Ezra is not said to eat from the tree of life, or the like, his use and non-use of foodstuffs and the symbolism associated with the foodstuffs, wisdom, and paradise

69 It may also be noted that in 8:10-11 the nourishing of a human being through God's provision is mentioned specifically by means of drinking the fruit of the breasts (i.e., milk) which leads to a human being's education in God's law and wisdom. 
in 4 Ezra do indicate that Ezra-along with his presumed audience-is well on his way towards the eschatological garden.

Thus, many, if not most, aspects of the use of literary motifs related to foodstuffs and their consumption in 4 Ezra are connected to the work's literary development and to the expression of its message. At the same time, they show how the work is part of the apocalyptic imagination of its time and is well aware of social conventions with regard to, notably, fasting and other techniques related to divine-human communication. 